\title{
PENINGKATAN LAYANAN PERPUSTAKAAN IPDN KAMPUS JAKARTA MELALUI SISTEM PERPUSTAKAAN DIGITAL
}

\author{
BOGA PRATALA \\ Perpustakaan Kampus IPDN Jakarta \\ Email : b.pratala@yahoo.com
}

\begin{abstract}
ABSTRAK
Sistem perpustakaan digital adalah penerapan teknologi informasi sebagai sarana untuk menyimpan, mendapatkan dan menyebarluaskan informasi ilmu pengetahuan dalam format digital. Atau secara sederhana dapat dianalogikan sebagai tempat menyimpan koleksi perpustakaan yang sudah dalam bentuk digital. Saat ini, Perpustakaan IPDN Kampus Jakarta belum memiliki sistem perpustakaan digital dikarenakan kurangnya perhatian Pimpinan, terbatasnya anggaran, dan kurangnya Sumber Daya Manusia yang mengelola perpustakaan. Kendala yang dihadapi Perpustakaan IPDN Kampus Jakarta ini menyebabkan menurunnya layanan peminjaman, layanan referensi, layanan Penelusuran Informasi, dan layanan Internet. Untuk mengatasi ini, diperlukan sistem perpustakaan digital di lingkungan Perpustakan Kampus Jakarta. Hal ini memerlukan sarana dan prasarana yang memadai, sumber daya manusia yang menguasai teknologi, dan anggaran yang mencukupi.
\end{abstract}

Kaca Kunci: Perpustakaan Digital, Perpustakaan IPDN Kampus Jakarta, Layanan Perpustakaan

\section{ABSTRACT}

Digital library system is an application of information technology that keep, obtain and disseminate the scientific information in digital format. In a simple analogy, it is a place to keep the digital library collections. Currently, Campus IPDN Jakarta Library does not yet have a digital library system due to the lack of attention from the leadership, limited budget, and lack of human resources who manage the library. The constraints faced by the Campus IPDN Jakarta Library have led to a decline in lending services, reference services, information retrieval services, and Internet services. To overcome it, a digital library system is needed in Campus IPDN Jakarta Library environment. This requires the adequate facilities and infrastructure, human resources who master technology, and an adequate budget.

Kaca Kunci: Digital Library, Campus IPDN Jakarta Library, Library Service

\section{PENDAHULUAN}

Perkembangan ICT di Indonesia menciptakan perpustakaan digital yang disambut baik para pengelola informasi atau pustakawan. Kebanyakan pustakawan terbuka terhadap perubahan teknologi, tetapi juga masih mengingat fungsi tradisional mereka, yaitu membantu orang untuk mencari informasi, baik dalam bentuk digital atau tercetak. Sosialisasi program perpustakaan digital terhadap para anggota jaringan dan para pengguna itu penting. Dalam hal ini, perlu peningkatan kesadaran akan fungsi utama mereka, yaitu memberikan kemudahan akses pengguna terhadap informasi. Untuk mempermudah akses, pustakawan perlu mendorong pengguna perpustakaan digital untuk melek informasi (information literate). Pengguna perpustakaan yang seperti ini adalah mereka yang sadar kapan memerlukan informasi dan mampu menemukan informasi, mengevaluasinya, dan menggunakan informasi yang dibutuhkannya itu secara efektif dan beretika.

Perpustakaan digital secara ekonomis lebih menguntungkan dibandingkan dengan perpustakaan tradisional. Chapman dan Kenney (Dalam Sismanto 2008), mengemukakan empat alasan yaitu: institusi dapat berbagi koleksi digital, koleksi digital dapat mengurangi kebutuhan terhadap bahan cetak pada tingkat lokal, penggunaannya akan meningkatkan akses elektronik, dan nilai jangka panjang koleksi digital akan mengurangi biaya berkaitan dengan pemeliharaan dan penyampaiannya. 
Berdasarkan permasalahan diatas, dapat dirumuskan permasalahan yaitu "Bagaimana peningkatan layanan Perpustakaan IPDN Jakarta melalui sistem perpustakaan digital?" Tujuan penulisan makalah ini adalah mendeskripsikan peningkatan layanan perpustakaan melalui sistem perpustakaan digital di lingkungan Perpustakaan IPDN Jakarta.

Strategi pengembangan perpustakaan digital dalam membangun aksesibilitas informasi menurut Hartono (2017) menekankan pada (1) pendekatan organisasi dan manajemen perpustakaan digital, (2) pendekatan implementasi teknologi informasi, (3) pendekatan kebijakan akses dan regulasi informasi, (4) pendekatan implementasi nilainilai keragaman budaya (multicultural) dan (5) mengembangkan kerjasama berbagi sumber daya (resource sharing).

Perpustakaan digital menawarkan kemudahan bagi para penggunanya untuk mengakses sumber informasi elektronik dengan alat yang menyenangkan pada waktu dan kesempatan yang terbatas. Pengguna tidak lagi terikat secara fisik pada jam layanan perpustakaan dimana pengguna harus mengunjungi perpustakaan untuk mendapatkan informasi. Banyak perpustakaan yang mengidamkan penerapan perpustakaan digital dalam pengelolaannya. Namun sayangnya banyak kendala yang dihadapi, diantaranya dana yang terbatas dan sumber daya manusia yang rendah ditengarai sebagai faktor dominan ketidakberdayaan mewujudkan sebuah perpustakaan digital.

Sismanto (2008) juga mengungkapkan bahwa gagasan perpustakaan digital ini diikuti Kantor Kementerian Riset dan Teknologi dengan program Perpustakaan Digital yang diarahkan memberi kemudahan akses dokumentasi data ilmiah dan teknologi dalam bentuk digital secara terpadu dan lebih dinamis. Upaya ini dilaksanakan untuk mendokumentasikan berbagai produk intelektual seperti tesis, disertasi, laporan penelitian, dan juga publikasi kebijakan. Kelompok sasaran program ini adalah unit dokumentasi dan informasi skala kecil yang ada di kalangan institusi pemerintah, dan juga difokuskan pada lembaga pemerintah dan swasta yang mempunyai informasi spesifik seperti kebun raya, kebun binatang, dan museum.

Perpustakaan harus bisa memberikan informasi yang dapat memuaskan penggunanya. Layanan yang baik, cepat, akurat dengan informasi yang sesuai kebutuhan pemakai harus selalu diusahakan. Layanan yang seperti itu dapat diberikan dengan bantuan teknologi informasi dan komunikasi (Saleh: 2015). Tantangan perpustakaan dimasa depan adalah bagaimana pustakawan dapat menguasai teknologi informasi dan komunikasi yang memang dibutuhkan untuk meningkatkan layanan perpustakaan Kampus IPDN Jakarta.

\section{METODE PENELITIAN}

Penelitian ini menggunakan metode studi kasus yang menguji secara rinci suatu tempat, orang, subjek, tempat penyimpanan dokumen, atau peristiwa tertentu dalam penulis mengenai stock opname koleksi di perpustakaan IPDN Kampus Jakarta. Penulis mengambil lokasi penelitian di perpustakaan IPDN Kampus Jakarta yang berada di Jl. Ampera Raya, kota Jakarta Selatan.

Data dan sumber data, data primer dalam penulisan ini diperoleh dari pengunjung perpustakaan sebanyak 25 (dua puluh lima) orang. Data sekunder merupakan sumber data yang didapat dari hasil survei. Instrumen survei yang dilakukan dalam penelitian diambil berdasarkan penelitian yang pernah dilakukan sebelumnya oleh Afriansyah (2012: 101) terhadap kepuasan layanan Perpustakaan Umum Kabupaten Sukabumi.

Tahap selanjutnya adalah menganalisis data. Analisis data merupakan proses mengorganisasikan, mengurutkan data kedalam pola,kategori, dan mengatur sehingga dirumuskan simpulan. Maka dalam penelitian ini menggunakan model analisis data Miles dan Huberman (1984: 63) dalam analisis data memiliki tiga proses yaitu "data reduction, data display, dan data drawing/verification. 


\section{HASIL DAN PEMBAHASAN}

Hasil

Faktor-faktor dalam penghitungan pendapat pengguna sesuai dengan dimensi bukti fisik (tangible), antara lain: kunjungan ke perpustakaan, lokasi perpustakaan, fisik gedung perpustakaan, kondisi sarana dan prasarana perpustakaan, penampilan pustakawan di perpustakaan, buku yang ada di rak dengan mudah ditemukan, kondisi fisik buku, dan koleksi buku dalam memenuhi kebutuhan pengguna. Berdasarkan faktor-faktor di atas, dapat dilihat nilai penghitungan rata-rata kepuasan pengguna dengan menggunakan tabulasi seperti di bawah ini:

Tabel 1. Intensitas Kunjungan Ke Perpustakaan Kampus IPDN Jakarta

\begin{tabular}{|l|c|c|}
\hline Jawaban & F & Persentase \\
\hline Sangat Sering & 1 & $4 \%$ \\
\hline Sering & 7 & $28 \%$ \\
\hline Kurang Sering & 10 & $40 \%$ \\
\hline Tidak Sering & 7 & $\mathbf{2 8 \%}$ \\
\hline Jumlah & $\mathbf{2 5}$ & $\mathbf{1 0 0 \%}$ \\
\hline
\end{tabular}

Dari tabel 1 dapat diketahui bahwa responden yang jumlah frekuensinya terbanyak adalah kunjungan kurang sering yaitu sebesar $40 \%$ atau sebanyak 10 orang. Sedangkan jumlah frekuensi kunjungan sering yaitu sebesar $28 \%$ atau sebanyak 7 orang, dan juga jumlah frekuensi kunjungan sangat sering sebesar $4 \%$ atau sebanyak 1 orang. Pada frekuensi tersebut yang memiliki skor terkecil atau tidak sama sekali yaitu pada kunjungan kurang sering.

Tabel 2. Lokasi Perpustakaan IPDN Kampus Jakarta

\begin{tabular}{|c|c|c|}
\hline Jawaban & F & Persentase \\
\hline Sangat Strategis & $\mathbf{3}$ & $\mathbf{1 2 \%}$ \\
\hline Strategis & $\mathbf{2 2}$ & $\mathbf{8 8 \%}$ \\
\hline Kurang Stategis & - & $\mathbf{0 \%}$ \\
\hline Tidak Strategis & - & $\mathbf{0 \%}$ \\
\hline Jumlah & $\mathbf{2 5}$ & $\mathbf{1 0 0 \%}$ \\
\hline
\end{tabular}

Berdasarkan data pada tabel 2 di atas, dapat diketahui bahwa persentase tanggapan responden terhadap pernyataan lokasi perpustakaan terbanyak adalah responden yang menjawab strategis yaitu $88 \%$ atau sebanyak 22 orang, yang menjawab sangat strategis yaitu $12 \%$ atau sebanyak 3 orang. Tidak ada responden yang menyatakan kurang strategis atau tidak strategis.

Berdasarkan persentase di atas, dapat diketahui bahwa responden yang menjawab pertanyaan mengenai lokasi Perpustakaan IPDN Kampus Jakarta adalah persentase yang menjawab strategis yaitu (88\%), hal ini dapat ditarik kesimpulan bahwa setengannya pengguna yang menjawab baik terhadap lokasi perpustakaan. Menurut Zethmal, Parasuraman dan Berry (1998: 148) denah dimana perpustakaan berada, penting diberikan. Petunjuk arah ditempatkan dilokasi yang strategis sehingga pengguna mudah menemukannya. Denah di dalam gedung juga perlu diperhatikan, apalagi biasanya gedung perpustakaan memiliki banyak lantai, karena kemudahan pengguna mendapatkan yang dibutuhkan sangat membantu kenyaman pengguna. 
Tabel 3. Fisik Gedung Perpustakaan IPDN Kampus Jakarta

\begin{tabular}{|c|c|c|}
\hline Jawaban & F & Persentase \\
\hline Sangat Baik & 1 & $4 \%$ \\
\hline Baik & $\mathbf{2 0}$ & $\mathbf{8 0 \%}$ \\
\hline Kurang Baik & 4 & $\mathbf{1 6 \%}$ \\
\hline Tidak Baik & - & $\mathbf{0 \%}$ \\
\hline Jumlah & $\mathbf{2 5}$ & $\mathbf{1 0 0 \%}$ \\
\hline
\end{tabular}

Berdasarkan data pada tabel 3 di atas, dapat diketahui bahwa persentase terbanyak adalah tanggapan responden terhadap fisik gedung perpustakaan adalah responden yang menjawab baik yaitu $80 \%$ atau sebnyak 20 orang. Responden yang menjawab sangat baik yaitu $4 \%$ atau sebanyak 1 orang, dan responden yang menjawab kurang baik yaitu $16 \%$ atau sebanyak 4 orang, dan tidak ada yang menjawab tidak baik terhadap fisik gedung perpustakaan IPDN Kampus Jakarta. Ini membuktikan bahwa ada tanggapan yang tidak puas terhadap fisik gedung dari Perpustakaan IPDN Kampus Jakarta.

Berdasarkan persentase di atas, dapat di ketahui bahwa persentase terbesar adalah responden yang menjawab baik terhadap fisik gedung perpustakaan yaitu (48\%), hal ini dapat disimpulkan bahwa hampir setengahnya pengguna yang menjawab baik terhadap fisik gedung perpustakaan. Menurut Zethmal, Parasuraman dan Berry dalam Lupiyoadi (2001:148) mengenai Posisioning perpustakaan sebagai tempat buku atau gudang buku masih kuat tertancap dibenak pikiran masyarakat. Lebih ironis lagi gedung perpustakaan dipersepsikan kotor, tua, berdebu dan statis. Fasilitas dan kegunaan perpustakaan yang lain menjadi tidak berarti. Pendapat seperti di atas harus segera diluruskan. Tempat yang nyaman, teduh, bersih dan membuat betah merupakan prioritas sebuah perpustakaan. Gedung perpustakaan juga harus lebih dinamis dalam merespon aktifitas pegawai dalam melayani pengguna, maupun kebutuhan tambahan pengguna.

Tabel 4. Kondisi Sarana dan Prasarana di Perpustakaan IPDN Kampus Jakarta
\begin{tabular}{|c|c|c|}
\hline Jawaban & F & Persentase \\
\hline Sangat Baik & 1 & $4 \%$ \\
\hline Baik & 18 & $72 \%$ \\
\hline Kurang Baik & 6 & $24 \%$ \\
\hline Tidak Baik & 0 & $0 \%$ \\
\hline Jumlah & 25 & $100 \%$ \\
\hline
\end{tabular}

Berdasarkan data pada tabel 4 di atas, dapat diketahui bahwa persentase terbanyak mengenai tanggapan responden terhadap kondisi sarana dan prasarana di perpustakaan adalah responden yang menjawab baik yaitu $72 \%$ atau sebanyak 18 orang. Responden yang menjawab sangat baik yaitu $4 \%$ atau sebanyak 1 orang, dan responden yang menjawab kurang baik yaitu $24 \%$ atau sebanyak 6 orang. Persentase terendah adalah responden yang menjawab tidak baik terhadap sarana dan prasaran di Perpustakaan IPDN Kampus Jakarta yaitu 0\% atau tidak ada sama sekali.

Berdasarkan persentase di atas, dapat diketahui bahwa jawaban responden mengenai kondisi sarana dan prasarana di Perpustakaan IPDN Kampus Jakarta adalah persentase terbesar yaitu jawaban responden yang menjawab baik yaitu (72\%), hal ini dapat ditarik kesimpulan bahwa lebih dari setengahnya pengguna menjawab baik terhadap kondisi sarana dan prasarana di perpustakaan. Untuk dapat meningkatkan sarana dan prasarana di 
Perpustakaan IPDN Kampus Jakarta, pustakawan dan pengelola perpustakaan menerima kritik dan saran dari pengguna yang telah berkunjung atau memakai fasilitas yang ada di perpustakaan tersebut, karena hal tersebut dapat menunjang kelangsungan hidup perpustakaan. Tanpa adanya pengguna, maka perpustakaan tersebut tidak akan berjalan dengan baik. Menurut Sutarno (2006:55) bahwa perpustakaan mempunyai peranan sebagai sarana dan prasarana untuk menjalin dan mengembangkan komunikasi antara semua pengguna, dan antara penyelenggara perpustakaan dengan masyarakat yang dilayaninya.

Tabel 5. Sikap Petugas Perpustakaan di Perpustakaan IPDN Kampus Jakarta

\begin{tabular}{|c|c|c|}
\hline Jawaban & F & Persentase \\
\hline Sangat Baik & $\mathbf{7}$ & $\mathbf{2 8 \%}$ \\
\hline Baik & $\mathbf{1 8}$ & $\mathbf{7 2 \%}$ \\
\hline Kurang Baik & - & $\mathbf{0 \%}$ \\
\hline Tidak Baik & - & $\mathbf{0 \%}$ \\
\hline Jumlah & $\mathbf{2 5}$ & $\mathbf{1 0 0 \%}$ \\
\hline
\end{tabular}

Berdasarkan data pada tabel 5 di atas, dapat diketahui bahwa persentase terbanyak mengenai sikap petugas pustakawan di Perpustakaan IPDN Kampus Jakarta adalah responden yang menjawab baik yaitu $72 \%$ atau sebanyak 18 orang. Responden yang menjawab sangat baik yaitu $28 \%$ atau sebanyak 7 orang. Tidak ada responden yang menjawab kurang baik dan tidak baik.

Berdasarkan persentase di atas, dapat diketahui bahwa jawaban responden mengenai sikap petugas Perpustakaan IPDN Kampus Jakarta adalah persentase yang terbesar yaitu responden yang menjawab baik (72\%), hal ini dapat disimpulkan bahwa setengahnya pengguna menjawab baik terhadap petugas perpustakaan. Oleh karena itu, petugas Perpustakaan IPDN Kampus Jakarta tetap menjaga profesionalisme dalam hal penampilan, karena penampilan yang baik dapat memberikan kenyaman dan kepuasan dari pengguna yang melihatnya. Untuk bisa mencapai kebutuhan pengguna tersebut pustakawan haruslah menjaga citra atau nama baik sebuah perpustakaan yang mereka kelola. Dalam hal tersebut dapat disimpulkan bahwa kepuasan dari pengguna perpustakaan tidaklah selalu ditinjau dari kualitas koleksi atau layananlayanan lainnya, tetapi dalam hal penampilan yang baik bisa memberikan pendapat pengguna yang diharapkan.

Tabel 6. Ketersediaan Buku di Rak yang Mudah Ditemukan

\begin{tabular}{|c|c|c|}
\hline Jawaban & F & Persentase \\
\hline Sangat Mudah & 1 & $\mathbf{4 \%}$ \\
\hline Mudah & $\mathbf{2 3}$ & $\mathbf{9 2 \%}$ \\
\hline Sulit & 1 & $\mathbf{4 \%}$ \\
\hline Sangat Sulit & - & $\mathbf{0 \%}$ \\
\hline Jumlah & $\mathbf{5 0}$ & $\mathbf{1 0 0 \%}$ \\
\hline
\end{tabular}

Berdasarkan data pada tabel 6 di atas, dapat diketahui bahwa persentase terbanyak mengenai buku yang ada di rak bisa dengan mudah ditemukan adalah responden yang menjawab mudah yaitu $92 \%$ atau sebanyak 23 orang. Responden yang menjawab sangat mudah yaitu $4 \%$ atau sebanyak 1 orang. Kemudian responden yang menjawab sulit yaitu $1 \%$ atau sebanyak 4 orang, dan tidak ada responden yang menjawab sangat sulit.

Berdasarkan persentase di atas, responden menjawab pertanyaan mengenai buku yang ada di rak dapat dengan mudah untuk ditemukan adalah mudah yaitu (92\%), hal ini dapat 
disimpulkan bahwa hampir setengahnya pengguna menjawab mudah dalam pencarian buku yang ada di rak. Berdasarkan penelitian yang dilakukan Sutardji dan Maulidyah (2006:33) Sistem layanan yang diterapkan di dalam suatu perpustakaan berpengaruh dalam menciptakan kepuasan penggunanya. Untuk mengakses informasi disediakan alat bantu penelusuran informasi seperti katalog, bibliografi, indeks dan daftar tambahan koleksi.

Tabel 7 Kondisi Fisik Buku

\begin{tabular}{|c|c|c|}
\hline Jawaban & F & Persentase \\
\hline Sangat Baik & $\mathbf{4}$ & $\mathbf{1 6 \%}$ \\
\hline Baik & $\mathbf{1 8}$ & $\mathbf{7 2 \%}$ \\
\hline Kurang Baik & $\mathbf{3}$ & $\mathbf{1 2 \%}$ \\
\hline Tidak Baik & - & $\mathbf{0 \%}$ \\
\hline Jumlah & $\mathbf{2 5}$ & $\mathbf{1 0 0 \%}$ \\
\hline
\end{tabular}

Berdasarkan data pada tabel 7 di atas, dapat diketahui bahwa persentase terbanyak mengenai kondisi fisik buku adalah responden yang menjawab baik yaitu $72 \%$ atau sebanyak 18 orang. Responden yang menjawab sangat baik yaitu $16 \%$ atau sebanyak 4 orang. Kemudian responden yang menjawab kurang baik yaitu $12 \%$ atau sebanyak 3 orang, dan tidak ada responden yang menjawab tidak baik.

Berdasarkan persentase di atas, dapat diketahui bahwa responden yang menjawab pertanyaan mengenai kondisi fisik buku yang ada di Perpustakaan IPDN Kampus Jakarta adalah responden yang menjawab baik yaitu $(72 \%)$, hal ini dapat ditarik kesimpulan bahwa lebih dari setengahnya pengguna menjawab baik terhadap kondisi fisik buku di perpustakaan. Karena kondisi fisik buku di perpustakaan mempengaruhi nilai kualitas dari suatu layanan di perpustakaan, untuk bisa menjadikan perpustakaan yang baik dan juga proporsional. Menurut Kotler dalam Lupiyoadi (2001:158) bahwa untuk menentukan tingkat kepuasan pengguna adalah kualitas koleksi, pengguna akan merasa puas bila hasil evaluasi mereka menunjukkan bahwa koleksi yang mereka gunakan berkualitas.

Tabel 8. Koleksi Buku Dalam Memenuhi Kebutuhan Pengguna

\begin{tabular}{|c|c|c|}
\hline Jumlah & F & Persentase \\
\hline Sangat Memenuhi & $\mathbf{2}$ & $\mathbf{8 \%}$ \\
\hline Memenuhi & $\mathbf{1 6}$ & $\mathbf{6 4 \%}$ \\
\hline Kurang Memenuhi & 7 & $\mathbf{2 8 \%}$ \\
\hline Tidak Memenuhi & - & $\mathbf{0 \%}$ \\
\hline Jumlah & $\mathbf{2 5}$ & $\mathbf{1 0 0 \%}$ \\
\hline
\end{tabular}

Berdasarkan data pada tabel 8 di atas, dapat diketahui bahwa persentase terbanyak mengenai koleksi buku dalam memenuhi kebutuhan pengguna adalah responden yang kurang memenuhi yaitu $7 \%$ atau sebanyak 28 orang. Kedua, jumlah persentase yang menjawab memenuhi yaitu $64 \%$ atau sebanyak 16 orang. Ketiga, jumlah persentase yang menjawab kurang memenuhi yaitu $8 \%$ atau sebanyak 2 orang, dan tidak ada responden yang menjawab tidak memenuhi.

Berdasarkan persentase di atas, dapat diketahui bahwa responden yang menjawab pertanyaan mengenai koleksi buku dalam memenuhi kebutuhan pengguna di Perpustakaan IPDN Kampus Jakarta adalah responden yang menjawab memenuhi yaitu (64\%), hal ini dapat disimpulkan bahwa koleksi buku di perpustakaan memberikan pengaruh yang besar terhadap kepuasan pengguna, karena tanpa adanya koleksi yang lengkap perpustakaan belum dinyatakan siap atau baik dalam menjalankan tujuannya yaitu memberikan layanan yang baik kepada 
pengguna khususnya dalam hal kelengkapan buku untuk memenuhi kebutuhan pengguna. Menurut Sutarno (2006:55) perpustakaan dapat berperan sebagai lembaga untuk mengembangkan minat baca, kegemaran membaca, kebiasaan membaca, dan budaya baca, melalui penyediaan berbagai bahan bacaan yang sesuai dengan keinginan dan kebutuhan masyarakat.

\section{KESIMPULAN}

Berdasarkan hasil penelitian dan pembahasan hasil maka di peroleh kesimpulan bahwa persentase terbesar yang didapatkan dari perhitungan yang dilakukan peneliti adalah pengguna menjawab baik terhadap sarana dan prasarana di Perpustakaan IPDN Kampus Jakarta. Dalam perhitungan survei pengguna yang dilakukan peneliti ini diharapkan bisa menjadi tolak ukur dalam pengembangan dan juga peningkatan terhadap layanan di Perpustakaan IPDN Kampus Jakarta. Hal yang paling utama dalam survei ini adalah bagaimana pengguna merasa kebutuhannya dilengkapi dan diberikan secara sepenuhnya, maka pengguna akan kembali lagi untuk dapat memanfaatkan layanan yang ada di perpustakaan.

Agar dapat meningkatkan kualitas layanannya, maka indikator-indikator yang dinilai belum memenuhi kebutuhan pengguna harus benar-benar diperhatikan dan ditingkatkan, seperti perlunya peningkatan layanan perpustakaan berbasis digital di Kampus IPDN Jakarta.

\section{DAFTAR PUSTAKA}

Hartono. 2017. Strategi Pengembangan Perpustakaan Digital Dalam membangun Aksesibilitas Informasi: Sebuah Kajian Teoritis Pada Perpustakaan Perguruan Tinggi Islam di Indonesia. Jurnal Perpustakaan Vol. 8 No.1 Tahun 2017: 75-91.

Miles, Matthew B. and A. Michael Huberman. 2005. Qualitative Data Analysis (terjemahan). Jakarta: UI Press.

Parasuraman, A., Zeithaml, V.A.and Berry, L.L. 1998. SERVQUAL: A Multiple Item Scale for Measuring Consumer Perceptions of Service Quality, Journal of Retaling, vol. 64 No, 1, pp. 12-40.

Perpustakan Nasional RI. 2008. Pedoman Umum Penyelenggaraan Perpustakaan Sekolah. Jakarta: Perpustakaan Nasional RI.

Ramadhan, Afriansyah. 2012. Survei Pendapat Pengguna Terhadap Layanan Perpustakaan Umum Kabupaten Sukabumi. Depok: Universitas Indonesia.

Saleh, Abdul Rahman. 2005. Pendayagunaan Layanan Perpustakaan Berbasis Teknologi Informasi. Jurnal Pustakawan Indonesia, jurnal.ipb.ac.id.

Sismanto. 2008. Manajemen Digital. http://mkpd.wordpress.com/2008/09/08/kupas-buku-manajemen-perpustakaandigital, diakses tanggal 4 Desember 2021.

Surat Keputusan Menteri Pendidikan dan Kebudayaan Nomor 0103/0/1981 tentang pokokpokok kebijaksanaan pembinaan dan pengembangan perpustakaan di Indonesia.

Sutarno, N.S. 2006. Peranan Perpustakaan dan Masyarakat. Jakarta: Sagung Sego.

Undang-Undang Nomor 43 Tahun 2007 Tentang Perpustakaan. 